\title{
JOURNAL OF RESEARCH IN \\ Higher Education
}

VoL. 1, No. 2 / 2017 


\section{Journal of Research in}

Higher Education

- Vol. I, No. 2, 2017

Published twice yearly by

(C) The Centre for University Strategy and Quality Management, University Babeș-Bolyai

\footnotetext{
ISSN 2559 - 6624

ISSN-L 2559 - 6624
}

https://doi.org/10.24193/JRHE.2017.2 
Edited by: Centre for University Strategy and Quality Management, University Babeş-Bolyai

\section{Editor-in-Chief}

Prof. Dan Chiribucă, University Babeș-Bolyai, Cluj-Napoca, Romania

\section{Editorial Board}

Professor Daniel DAVID, University Babes-Bolyai, Romania

Associate Professor MARKO Balint, University Babes-Bolyai, Romania

Professor Adrian HATOS, University of Oradea, Romania

Associate Professor William Yat Wai Lo, Hong Kong Institute of Education,

China

Prof. Ian McNAY, University of Greenwich, UK

Associate Professor Bogdan NADOLU, West University of Timișoara, Romania,

President of Romanian Sociologists Society

Professor Marian PREDA, University of Bucharest, Romania

Professor Horatiu RUSU, Lucian Blaga University of Sibiu, Romania

Associate Professor Pedro TEIXEIRA, University of Porto, Portugal

Professor Robert TOUTKOUSHIAN, University of Georgia USA

Professor Eyüp ARTVINLI, Eskisehir Osmangazi University, Turkey

\section{Executive Editors}

Dr. Simona Mălăescu

Dr. Sonia Pavlenko

Dr. Oana Mihaela Tămaş

Language Editor:

Dr. Sonia Pavlenko

(C) Cover design

Edit Fogarasi

All material copyright (C)2017 by the Centre for University Strategy and Quality Management, University Babeș- Bolyai. Reproduction or use without written permission is prohibited.

e-mail: journal.rehe@ubbcluj.ro

http://jrehe.reviste.ubbcluj.ro/ 


\section{Contents}

Simona Torotcoi Politics and Policies of Higher Education: Policy Transfer and the Bologna Process

Daniel David, Ovidiu The 2017 University Metaranking. 31 Andronesi, Carmen Romanian University Ranking Buzea, Bogdan Florian, Silviu Matu \& Lazăr Vlăsceanu

Claudia Rus, Sofia University Culture: An Analysis at 51 Chirică, Dan the Level of Research and Chiribucă \& Simona Educational units (using the Mălăescu Competing Values Framework)

Sonia Pavlenko, Cristina Bojan The University between Theory 83 and Practice. How Romanian Aspiring University Leaders Understand the University

Attila Gábora, Simona Pull Factors Attracting Romanian Mălăescu, Sonia Students to Babeș-Bolyai University Pavlenko 
